\title{
Pelaksanaan Hak Tahanan (Tantangan Dan Permasalahan)
}

\author{
Monika Dwi Putri Nababan, Kabib Nawawi \\ Fakultas Hukum, Universitas Jambi \\ Author's email correspondence: monikadwiputri@gmail.com
}

\begin{abstract}
ABSTRAK
Penelitian ini bertujuan untuk membahas pelaksanaan hak tahanan dan kendala yang dihadapi Lembaga Pemasyarakatan dalam memberikan hak tahanan. Penelitian ini bersifat yuridis empiris. Hasil penelitian menunjukkan bahwa pelaksanaan hak tahanan masih belum efektif terkait beberapa hak, diantaranya yaitu hak untuk melakukan ibadah yakni terkait melaksanakan tempat ibadah tidak tersedia bagi semua agama yang diakui di Indonesia, kurangnya tenaga medis bagi layanan kesehatan, hak menyampaikan keluhan dimana keluhan tahanan kurang mendapat tanggapan dari petugas lapas dan hak mendapatkan kunjungan yang kurang nyaman serta hak mendapatkan politik. Kendala yang dialami oleh Lembaga Pemasyarakatan dalam memberikan hak tahanan diantaranya: kapasitas berlebih Lembaga Pemasyarakatan, keterbatasan sarana dan prasarana yang mendukung di Lembaga Pemasyarakatan, kurangnya tenaga pengajar pembinaan, tenaga kesehatan dan tenaga bantuan lainnya, kurangnya anggaran dana serta tidak semua tahanan bersedia mengikuti program yang diberikan oleh petugas Lembaga Pemasyarakatan
\end{abstract}

Kata Kunci: Hak Tahanan; Lembaga Pemasyarakatan; Pelaksanaan.

\section{ARTICLE HISTORY}

Submission: 12 December 2020

Accepted: 03 February 2020

Publish: 07 February 2020

\section{KEYWORDS}

Correctional Institution; Detention

Rights; Implementation

Detention Rights;

Implementation

\begin{abstract}
This study aims to discuss the implementation of prisoners' rights and the constraints faced by the Penitentiary in providing prisoners' rights. This research is empirical research. The results showed that the implementation of the right of detainees was still ineffective in relation to several rights, including the right: to conduct worship, namely related to carrying out places of worship not available to all religions, lack of medical personnel for health services, the right to submit complaints where complaints from prisoners did not get a response from prison officers and the right to get uncomfortable visits and the right to get politics. Constraints experienced by Penal Institutions in granting prisoners' rights include: overcrowding capacity of Penitentiaries, limited facilities and infrastructure that support in Penitentiaries, lack of guidance teaching staff, health workers and other aid workers, lack of budget funds and not all prisoners are willing to participate in programs that given by the Penitentiary officer.
\end{abstract}

\section{A. PENDAHULUAN}

Perlindungan hak asasi merupakan perlindungan yang wajib diberikan oleh negara kepada setiap warga negara. Hal ini dimuat dalam UUD 1945 Pasal 27 Ayat (2) yang menentukan: “Menjunjung tinggi hak asasi Manusia serta menjamin segala 
warga Negara bersamaan kedudukannya di dalam hukum dan pemerintahan itu dengan tidak ada pengecualian".

Menurut Bahder Johan Nasution, Negara hukum (rechstaat), terdapat ciri-ciri sebagai berikut:

a. Adanya Undang-Undang Dasar atau Konstitusi yang memuat ketentuan tertulis tentang hubungan antara pengusaha dan rakyat

b. Adanya pemisahan kekuasaan Negara, yang meliputi: kekuasaan pembuat undang-undang yang berada pada parlemen, kekuasaan kehakiman yang bebas dan merdeka, kekuasaan ini tidak hanya menangani sengketa antar individu rakyat, tetapi juga antara rakyat dengan penguasa dan pemerintah mendasarkan tindakannya atas undang-undang (wetmatig bestuur)

c. Diakuinya dan dilindunginya hak-hak rakyat yang sering disebut "vrijheidsrechten van burger".1

Negara Republik Indonesia (RI) sebagai lembaga kekuasaan tertinggi mempunyai kewajiban untuk melindungi Hak Asasi Manusia (HAM) warganya melalui sarana hukum yang terintegrasikan dalam Undang-Undang Nomor 39 Tahun 1999 Tentang Hak Asasi Manusia (HAM). Hal ini berangkat dari suatu kenyataan bahwa setiap manusia terlahir dengan membawa sesuatu yang hakiki dan universal serta melekat sejak dilahirkan di muka bumi ini sebagai anugerah dari Tuhan Yang Maha Esa yaitu hak yang harus dijunjung tinggi, dihormati serta dijaga agar tidak merusak apa yang telah diamanatkan. ${ }^{2}$

Berdasarkan ketentuan tersebut dapat disimpulkan bahwa Negara Republik Indonesia sangat menjunjung tinggi hak asasi manusia dan persamaan kedudukan dihadapan hukum. Seperti dalam hal seorang warga negara yang disangka telah melakukan tindak pidana, orang tersebut harus dilindungi dan diperlakukan sebagai pihak yang belum bersalah sesuai dengan asas praduga tak bersalah sebelum adanya putusan yang mempunyai kekuatan hukum yang tetap yang menyatakan kesalahannya. Sehingga seorang yang disangka melakukan tindak pidana tersebut harus diperlakukan sesuai dengan ketentuan undang-undang yang berlaku. "Dari segi hukum pidana maka kepentingan masyarakat lebih diutamakan dari kepentingan orang seorang (individu), yang dalam kehidupan sehari-hari disebut kepentingan umum". 3

Untuk memenuhi hak asasi seseorang dalam proses peradilan, Indonesia memiliki Undang-Undang Nomor 8 Tahun 1981 Tentang Undang-Undang Hukum

Bahder Johan Nasution, Negara Hukum dan Hak Asasi Manusia, Mandar Maju, Jambi, 2014, hlm. 6.

2 Baharudin Lopa, Pasal 12 Universitas Declaration Of Human Right Kejahatan Korupsi dan Penegakan, Sinar Grafika, Jakarta, 2009, hlm 149.

3 Leden Marpaung, Proses Penanganan Perkara Pidana (Penyelidikan dan Penyidikan), Edisi Kedua, Sinar Grafika, Jakarta, 2014, hlm. 20. 
Acara Pidana (KUHAP) yang disahkan pada tanggal 31 Desember 1981 sebagai pedoman dalam melakukan proses peradilan yang dianggap mampu mendapatkan atau setidak-tidaknya mendekati kebenaran materiil dari suatu perkara dalam tatanan hukum acara positif. Hal ini sejalan dengan arah pembangunan hukum yang menekankan kodifikasi dan unifikasi hukum acara pidana yang mampu melindungi dan mengayomi seluruh warga Negara Indonesia yang berdasarkan kepada Pancasila dan Undang-Undang Dasar 1945.

Dalam rangka perlindungan hak asasi manusia, di lingkungan peradilan dikenal dengan adanya asas praduga tak bersalah yang tertuang dalam Pasal 8 Ayat (1) Undang-Undang Nomor 48 Tahun 2009 Tentang Kekuasan Kehakiman, yang menyatakan: "Setiap orang yang disangka, ditangkap, ditahan dan dituntut, atau dihadapkan di depan pengadilan, wajib dianggap tidak bersalah sebelum adanya putusan pengadilan yang menyatakan kesalahannya dan memperoleh kekuatan hukum yang tetap". M. Yahya Harahap mengatakan bahwa:

Tersangka harus ditempatkan pada kedudukan manusia yang memiliki hakikat martabat. Yang menjadi objek pemeriksaan adalah perbuatan tindak pidananya bukan manusia tersangkanya, jadi tersangka harus diperlakukan dan dianggap tidak bersalah sesuai dengan asas praduga tak bersalah sampai diperoleh putusan pengadilan yang telah berkekuatan hukum. ${ }^{4}$

Asas praduga tak bersalah ditinjau dari segi teknis yuridis ataupun dari segi teknis penyidikan dinamakan prinsip akusatur atau accusatory procedure.

Prinsip akusatur menempatkan kedudukan tersangka atau terdakwa dalam setiap tingkat pemeriksaan:

a. Adalah subjek: bukan sebagai objek pemeriksaan, karena itu tersangka atau terdakwa harus didudukkan dan diperlakukan dalam kedudukan manusia yang mempunyai harkat martabat harga diri.

b. Yang menjadi objek pemeriksaan dalam prinsip akusatur adalah "kesalahan"(tindakan pidana) yang dilakukan oleh tersangka/terdakwa. Kearah itulah pemeriksaan ditujukan. ${ }^{5}$

Menurut Soeharto fungsi dari suatu Undang-Undang acara pidana adalah untuk membatasi kekuasaan Negara dalam melindungi setiap masyarakat yang terlibat dalam proses peradilan pidana, sehingga terjamin perlindungan para tersangka dang terdakwa dari tindakan aparat penegak hukum dan pengadilan. ${ }^{6}$ Sedangkan menurut Tolib Effendi fungsi hukum acara pidana yaitu untuk mencari

4 M. Yahya Harahap, Pembahasan permasalahan dan Penerapan KUHAP, Sinar Grafika, 2000, hlm.34.

5 M. Yahya Harahap, Pembahasan permasalahan dan Penerapan KUHAP, hlm. 40.

6 H. Soeharto, Perlindungan Hak Tersangka, Terdakwa dan Korban Tindak Pidana Terorisme dalam Sistem Peradilan Pidana Indonesian, PT Refika Aditama, Bandung, 2007, hlm. 73. 
dan menemukan kebenaran, Pengambilan keputusan oleh Hakim, dan untuk pelaksanaa dari pada putusan tersebut. ${ }^{7}$ Dengan demikian hukum yang sama memberikan pembatasan-pembatasan terhadap hak asasi warganya. Pasal 16 KUHAP menunjukkan bahwa perintah penangkapan tidak dapat dilakukan dengan sewenang-wenang, tetapi ditujukan kepada mereka yang betul-betul melakukan tindak pidana. ${ }^{8}$

Dalam penerapan penegakan hukum terdapat landasan asas atau prinsipprinsip yang diartikan sebagai dasar patokan hukum yang melandasi Kitab Undang-Undang Hukum Acara Pidana (KUHAP). Asas inilah tonggak pedoman bagi instansi jajaran aparat penegak hukum dalam menerapkan KUHAP, prinsip-prinsip itu meliputi:

a. Asas legalitas

b. Asas Keseimbangan

c. Asas Praduga Tak Bersalah

d. Prinsip Pembatasan Penahanan

e. Asas Ganti Rugi dan Rehabilitasi

f. Penggabungan Pidana dengan Tuntutan Ganti Rugi

g. Asas Unifikasi

h. Prinsip Saling Koordinasi

i. Asas Peradilam Sederhan, Cepat dan Biaya Ringan

j. Prinsip Peradilan Terbuka untuk Umum. ${ }^{9}$

Peranan aparat penegak hukum dalam proses penegakan hukum sangat menentukan arah dan tujuan serta hasil yang akan dicapai dalam penegakan hukum itu sendiri. Selain itu, hal lain yang menjadi faktor penting dalam menentukan efektifitas penegakan hukum adalah masalah kesadaran hukum oleh subjek hukumnya sendiri. Dalam sistem peradilan pidana kita mengenal Kepolisian, Kejaksaan, Pengadilan dan Lembaga Pemasyarakatan. Namun dalam hal ini yang paling utama adalah peranan para pemimpin pada negara yang sedang berkembang sesungguhnya sangat menentukan, khususnya dalam pembinaan aparat penegak hukum. ${ }^{10}$

Lembaga Pemasyarakatan merupakan institusi muara akhir dari penyelenggaraan prose peradilan. Penyelenggaraan peradilan pidana merupakan rangkaian mekanisme aparat penegak hukum pidana mulai dari Polisi, Jaksa, Hakim dan petugas Lembaga Pemasyarakatan. Dengan perkataan lain peradilan pidana merupakan suatu sistem yang terdiri dari beberapa sub sistem peradilan pidana dimana masing-masing sub sistem tersebut mempunyai kewenangan sesuai dengan ketetapan undang-undang dalam rangka mencapai tujuan peradilan pidana yaitu

Tolib Effendi, Dasar-Dasar Hukum Acara Pidana, Setara Press, Malang, 2014, hlm. 5.

8 M. Yahya Harahap, Op.Cit, hlm.158.

Ibid, hlm. 35.

10 Leden Marpaung, Proses Penanganan Perkara Pidana (Penyelidikan dan Penyidikan), hlm. 51. 
penanggulangan kejahatan dan pencegahan kejahatan. ${ }^{11}$ Penanggulangan kejahatan bukan persoalan sederhana namun menyangkut permasalahan kompleks yang butuh solusi terbaik yang melibatkan berbagai pihak. Lembaga Pemasyarakatan bukan saja sebagai wadah pembinaan bahkan juga berkumpulnya para tahanan yang juga sering menimbulkan persoalan yang kompleks. Tahanan yang ada di Lembaga Pemasyarakatan memiliki hak hak yang wajib dipenuhi oleh negara.

Di Lembaga Pemasyarakatan narapidana diberikan pembinaan berdasarkan sistem pemasyrakatan: "Sistem Pemasyarakatan adalah suatu tatanan mengenai arah dan batas serta cara pembinaan Warga Binaan Pemasyarakatan berdasarkan Pancasila yng dilaksanakan secara terpadu antara pembina, yang dibina, dan masyarakat untuk meningkatkan kualitas Warga Binaan agar menyadari kesalahan, memperbaiki diri, dan tidak mengulangi tindak pidana sehingga dapat diterima oleh lingkungan masyarakat, dapat aktif berperan dalam pembangunan, dan dapat hidup secara wajar sebagai warga yang baik dan bertanggung jawab.12 Lembaga Pemasyarakatan sebagai salah satu organisasi publik yang merupakan unit pelaksana Direktorat Jendral Pemasyarakatan Departemen Hukum dan HAM, mempunyai tugas pokok melaksanakan pembinaan terhadap narapidana. ${ }^{13}$

Berkenaan dengan hak tahanan, menurut PP Nomor 58 Tahun 1999 Tentang Syarat Dan Tata Cara Pelaksanaan Wewenang, Tugas Dan Tanggung Jawab Perawatan Tahanan dalam Bab IV Pasal 11 sampai dengan Pasal 41 menggariskan bahwa:

a. Setiap tahanan berhak untuk melakukan ibadah sesuai dengan agama dan kepercayaannya masing-masing (Pasal 11 sampai dengan Pasal 13).

b. Setiap tahanan berhak mendapatkan perawatan rohani dan jasmani (Pasal 14 sampai dengan Pasal 19).

c. Setiap tahanan diberikan kesempatan mengikuti pendidikan dan pengajaran (Pasal 20).

d. Setiap tahanan berhak memperoleh pelayanan kesehatan dan makanan yang layak (Pasal 21 sampai dengan Pasal 33).

11 Hafrida, Yulia Monita, Elizabeth Siregar, Publikasi Pendidikan Jurnal Pemikiran, Penelitian, dan Pengabdian Masyarakat Bidang Pendidikan, Volume V Nomor 3, 2015, hal.201. https://ojs.unm.ac.id/index.php/pubpend/article/view/1613/0

12 Dwija Priyatno, Sistem Pelaksanaan Pidana Penjara di Indonesia, Refika Aditama,Bandung, 2006, hlm.106.

13 Romli Atmasasmita, Sistem Peradilan Pidana Kontemporer, Kencana, Jakarta, 2008, hlm.2. 
e. Setiap tahanan berhak menyampaikan keluhan tentang perlakuan pelayanan petugas atau sesama tahanan kepada Kepala RUTAN/Cabang RUTAN atau LAPAS/Cabang LAPAS (Pasal 34).

f. Setiap tahanan berhak mendapatkan bahan bacaan dan siaran media massa (Pasal 34 sampai dengan Pasal 36).

g. Setiap tahanan berhak menerima kunjungan dari (Pasal 37 sampai dengan Pasal $40)$.

1.Keluarga dan atau sahabat;

2. Dokter pribadi;

3. Rohaniawan;

4. Penasihat hukum;

5. Guru; dan

6. Pengurus dan atau anggota organisasi sosial kemasyarakatan.

h. Hak-hak lain

Tahanan tetap mempunyai hak politik dan hak keperdataan sesuai dengan perundang-undangan yang berlaku (Pasal 41).

Merujuk pada aturan di atas memberikan konsekwensi pada negara bahwa pemenuhan hak tersebut merupakan kewajiban negara yang harus dilaksanakan. Hak-hak tersebut terkait berbagai bidang, seperti bidang rohani, pendidikan bahkan politik dan keperdataan.

Jika menelaah pada jumlah tahanan yang menjalani masa tahanan di Lembaga Pemasyarakatan Klas IIA Jambi, ada hal yang menarik, yang perlu mendapat perhatian. Bahwa dalam kurun waktu periode Januari sampai dengan April 2019 dari segi kuantitas menunjukkan angka yang sangat signifikan seperti dalam tabel berikut:

Tabel. 1

Jumlah Tahanan di Lembaga Pemasyarakatan Klas IIA Jambi Periode April 2019

\begin{tabular}{ccccc}
\cline { 3 - 4 } No & \multirow{2}{*}{ Bulan } & \multicolumn{2}{c}{ Jumlah Tahanan } & \multirow{2}{*}{ Total } \\
\cline { 3 - 4 } & & Laki-laki & Perempuan & \\
\hline 1 & Januari & 326 & 15 & 341 \\
\hline 2 & Februari & 351 & 20 & 371 \\
\hline 3 & Maret & 333 & 18 & 351 \\
\hline 4 & April & 383 & 22 & 405 \\
\hline
\end{tabular}

Sumber: Lembaga Pemasyarakatan Klas IIA Jambi. Sabtu, 25 Mei 2019

Jumlah tahanan yang cukup besar sebenarnya akan memberikan dampak yang negatif bagi tahanan, di samping kompleksitasnya hak hak tahanan yang harus 
dipenuhi oleh negara. Upaya mengurangi kepadatan lembaga pemasyarakatan dengan mempercepat reintegrasi narapidana adalah bagian dari kebijakan sistem pemidanaan yang berorientasi dengan pemasyarakatan. ${ }^{14}$ Persoalan ini juga menjadi permasalahan bagi Lembaga Pemasyarakatan. Namun lebih dari itu, sebenarnya pemenuhan hak-hak tahanan adalah persoalan awal yang komplek dan merupakan tantangan besar bagi Lembaga Pemasyarakatan Jambi.

Berdasarkan pembahasan di atas, permasalahan yang dipaparkan dalam artikel ini adalah Bagaimana Pelaksanaan Hak Tahanan ? Dan Apakah kendala yang dihadapi dalam pemenuhan hak tahanan (tantangan dan permasalahan) ?

Berdasarkan pada ketentuan Peraturan Perundang-Undangan yang berlaku di Negara Republik Indonesia, pelanggaran yang dilakukan seseorang terhadap hak orang lain, dapat menimbulkan pelanggaran hukum. Dalam hal adanya dugaan telah terjadi sebuah pelanggaran hukum, maka hak seseorang yang disangka melakukan pelanggaran hukum atau tersangka tersebut haruslah tetap dilindungi, dihormati dan dipenuhi.

Dalam artikel ini penulis bertujuan memberikan gambaran atau memaparkan tentang pelaksanaan hak tahanan (tantangan dan permasalahan), yang terjadi di tempat penelitian penulis yaitu di wilayah Kota Jambi (studi tahanan yang berada di Lembaga Pemasyarakatan Klas II A Jambi)..

B. Metode Penelitian

Metode dalam penelitian ini menggunakan yuridis emipiris yaitu pendekatan yang digunakan untuk melihat gejala-gejala sosial yang berkaitan dengan hukum dalam praktek legislasi di Indonesia.

\section{Pembahasan}

1. Pelaksanaan hak tahanan di wilayah hukum Kota Jambi (studi tahanan yang berada di Lembaga Pemasyarakatan Klas IIA Jambi)

Hak asasi manusia adalah hak yang dimiliki oleh setiap manusia yang hidup menurut kodrat yang melekat dan tidak dapat dipisahkan dari hakikatnya. Manusia hidup dengan melindungi dan mempertahankan haknya. Setiap manusia berhak untuk mempertahankan hidupnya serta berhak mendapatkan perlindungan terhadap hak yang dimilikinya, begitu pula dengan tahanan yang meskipun diduga

14 Galih Puji Mulyono, Barda Nawawi Arief, Upaya Mengurangi Kepadatan Narapidana Dalam Lembaga Pemasyarakatan Di Indonesia, Jurnal Law Reform, Program Magister Ilmu Hukum, Fakultas Hukum Unidp, Volume 12 Nomor 1, 2016, hal. https://ejournal.undip.ac.id/index.php/lawreform/article/view/15838 
telah melakukan kesalahan atau melanggar hukum tetap mempunyai hak untuk mempertahankan hidup dan mendapatkan perlindungan hukum terhadap haknya. Dapat dilihat bahwa fungsi dari Lembaga Pemasyarakatan adalah melakukan pembinaan bagi warga binaan pemasyarakatan berdasarkan sistem, kelembagaan dan cara pembinaan sebagai bagian akhir dari sistem pemidanaan dalam sistem peradilan pidana. ${ }^{15}$ Sekalipun tersangka atau terdakwa berada dalam penahanan, bukan berarti dapat diperlakukan sewenang-wenang. Lembaga Pemasyarakatan Klas IIA Jambi sebagai perangkat Negara memiliki kewajiban untuk memenuhi hak tahanan tersebut. Untuk menjaga agar seluruh hak dasar tahanan tidak terabaikan sudah menjadi tanggung jawab Lembaga Pemasyarakatan Klas IIA Jambi. terkait dengan hal tersebut penulis menjabarkan hak tahanan yang diberikan berdasarkan Peraturan Pemerintah Nomor 58 tahun 1999 Tentang Syarat Dan Tata Cara Pelaksanaan Wewenang, Tugas Dan Tanggung Jawab Perawatan Tahanan dalam Bab IV sebagai berikut:

a. Hak melakukan ibadah

Pelaksanaan hak melakukan ibadah di Lembaga Pemasyarakatan Klas IIA Jambi sudah baik. Berdasarkan hasil penelitian penulis dalam bentuk wawancara dengan salah satu tahanan atas nama Mansur beragama Islam, beliau mengatakan bahwa pelaksanaan ibadah di Lembaga Pemasyarakatan Klas IIA Jambi sudah cukup memadai. Menurut beliau Kegiatan shalat lima waktu bagi umat muslim dilaksanakan secara berjamaah di masjid, yang beragama budha dilaksanakan setiap hari selasa di wihara dan bagi yang beragama Kristen dilakukan setiap hari di gereja, ketika sedang melakukan ibadah misalnya ibadah shalat, selain didalam kamar blok ia juga sering melaksanakannya di Masjid yang sudah disediakan terkadang tahanan yang malas untuk menggunakannya.

Menurut bapak Sudarto "Pihak Lapas telah semaksimal mungkin memfasilitasi tempat dan kegiatan dalam beribadah, setiap tahanan diajak dan menghimbau untuk lebih mendekatkan diri kepada Tuhan. Namun jika ada tahanan yang tidak mengikuti, petugas tidak dapat memaksakan, karena ibadah harus niat dari hati". ${ }^{16}$ Terkait dengan sarana dan prasaranan yang diberikan, di Lapas Klas IIA Jambi telah tersedia rumah ibadah berupa masjid, gereja dan wihara.

15 Adi Sujatno, Pencerahan di Penjara, Refika Aditama, Bandung, 2008, hlm. 136-137.

16 Hasil wawancara dengan Bapak Sudarto, Kepala Sub Bagian Tata Usaha Lembaga Pemasyarakatan Klas IIA Jambi, pada tanggal 27 Mei 2019. 
b. Hak mendapatkan perawatan rohani dan jasmani

Perawatan rohani di Lapas Klas IIA Jambi dilaksanakan dengan memberikan bimbingan rohani kepada tahanan, yaitu dengan memberikan pengetahuan yang membentuk sikap, kepribadian dan keterampilan peserta didik dalam mengamalkan ajaran agamanya. Bimbingan rohani tersebut berupa dilakukan tadabbur quran bagi yang beragama islam yang bertujuan untuk mempelajari dan memahami ayat-ayat Al-Quran yang dilaksanakan setiap hari senin dan kamis pukul 10.00 WIB. Ceramah yang bernuansa islam dilaksanakan setiap hari selasa dan rabu pukul 15. $00 \mathrm{WIB}$, serta pendidikan Al-Quran orang dewasa yang bertujuan untuk memperbaiki bacaan Al-Quran yang dilaksanakan setiap hari jumat pukul 13.00 WIB. Dan untuk yang beragama Kristen diberikan kegiatan ceramah senin sampai minggu pukul 09.00 WIB yng bertempat di gereja. Yang beragama budha dan konghucu pun diberikan kegiatan ceramah secara bergantian.

Dalam hal perawatan jasmani dilaksanakan dengan cara memberikan kegiatan pembinaan jasmani yang bertujuan untuk memperoleh pertumbuhan jasmani, kesehatan dan kesegaran jasmani, kemampuan keterampilan, kecerdasan dan perkembangan watak atau kepribadian yang harmonis serta dapat menerima orang lain sebagaimana adanya dan mempunyai sikap positif terhadap diri sendiri maupun orang lain. Lembaga Pemasyarakatan Klas IIA Jambi memberikan sarana prasarana berupa kegiatan olahraga seperti senam pagi, voli, tenis meja, raket dan tenis lapangan. Hanya saja fasilitas yang diberikan untuk raket kurang tepat.

c. Hak Mendapatkan Pendidikan dan Pengajaran

Di Lapas Klas IIA Jambi pendidikan yang diberikan adalah penyuluhan hukum dan pembinaan kepribadian berupa bimbingan agama. Menurut penelitian penulis penyuluhan hukum yang diberikan tidak merata kepada tahanan, ada tahanan yang sudah mendapat penyuluhan hukum sebanyak 3 kali namun ada juga tahanan yan tidak pernah mengikuti penyuluhan hukum. Menanggapi hal itu bapak Sudarto mengatakan bahwa memang sangat tidak memungkinkan untuk memberikan penyuluhan hukum terhadap semua tahanan sekaligus dikarenakan fasilitas yang kurang memadai. ${ }^{17}$ Di Lembaga Pemasyarakatan para narapidana melakukan pembinaan di bidang keterampilan seperti pertukangan, menjahit, dan sebagainya, yang bertujuan

17 Hasil wawancara dengan Bapak Sudarto, Kepala Sub Bagian Tata Usaha Lembaga Pemasyarakatan Klas IIA Jambi, pada tanggal 27 Mei 2019. 
untuk memberikan bekal bagi narapidana setelah menjalani hukuman di Lembaga Pemasyarakatan sehingga bisa diterima kembali di tengah masyarakat, di dalam Lembaga Pemasyarakatan juga diperrsiapkan berbagai program pembinaan bagi para narapidana sesuai dengan tingkat pendidikan, jenis kelamin, dan jenis tindak pidana yang dilakukan narapidana, agar mereka menjadi warga yang baik di kemudian hari. ${ }^{18}$ Menurut penulis perwujudan pemenuhan hak pendidikan dan pengajaran terhadap tahanan masih tergolong kurang baik, hal ini dikarenakan pemberian hak yang tidak menyeluruh kepada tahanan mengakibatkan adanya tahanan yang tidak terpenuhi haknya. Walaupun fasilitas lapas kurang memadai harusnya pihak lapas memberikan penyuluhan secara bergantian dengan tidak memberikan secara acak.

d. Hak Mendapatkan Perawatan Kesehatan dan Makanan Yang Layak

Dalam hal pelayanan kesehatan, Lembaga Pemasyarakatan Klas IIA Jambi memberikan sarana prasaranan berupa klinik dan tim medis yang terdiri dari 1 orang dokter umum, 1orang spikolog dan 4 orang perawat. Namun dalam pelayanannya tim medis terkadang kewalahan dengan banyaknya jumlah warga binaan yang harus diberikan perawatannya, terlebih lagi dengan adanya sistem jadwal piket yang mengakibatkan tim medis tidak selalu ada di klinik lapas. Selanjutnya terkait dengan pemberian makanan yang layak merupakan hak tahanan yang wajib dipenuhi. Makanan dengan kaidah gizi seimbang dibutuhkan oleh tahanan untuk mempertahankan dan meningkatkan derajat kesehatan agar tidak sakit dan dapat melakukan aktifitasnya sehari-hari. Tahanan diberikan makanan yang bergizi dan sesuai dengan jumlah kalori yang diperlukan perhari yaitu 2.250 kalori. Dan menu bergantian setiap hari sesuai dengan siklus menu 10 hari Lapas Klas IIA Jambi. Tahanan diberikan makanan sebanyak 3 (tiga) kali sehari dan snack 2 (dua) kali. Menurut penulis dalam pemenuhan makanan yang layak terhadap tahanan sudah baik, pihak lapas sudah semaksimal mungkin memenuhi kebutuhan makanan tahanan, hal ini dapat dilihat dari minimnya jumlah anggaran yang diberikan negara terhadap lapas.

e. Hak Menyampaikan Keluhan

Terkait dengan hak menyampaikan keluhan, penulis menggolongkan keluhan tahanan kedalam tiga kelompok, yaitu keluhan tahanan terhadap sarana dan prasarana di Lembaga Pemasyarakatan, keluhan tahanan terhadap perlakuan petugas terhadap tahanan dan keluhan tahanan terhadap perlakuan tahanan

18 Djisman Samosir, Penologi dan Pemasyarakatan,Nuansa Aulia, Bandung, 2012, hlm. 128. 
lainnya. Berdasarkan hasil penelitian yang dilakukan kepada tahanan, terungkap bahwa perlakuan para petugas Lembaga Pemasyarakatan Klas IIA Jambi pada umumnya berlaku baik terhadap tahanan. Hal ini tergambar melalui hasil wawancara dengan tahanan. Tahanan mengatakan bahwa mereka tidak mempunyai keluhan mengenai perlakuan petugas Lembaga Pemasyarakatan terhadap mereka. Akan tetapi terdapat keluhan tahanan terhadap sarana dan prasarana dan perlakuan antar tahanan lainya berupa perlakuan kasar maupun intimidasi. Namun keluhan tersebut tidak mendapat tanggapan lanjutan dari pihak lapas. Mengenai hal tersebut penulis melakukan wawancara dengan Bapak Suprihadi dan mengatakan bahwa:

Pelaksanaan hak tahanan untuk menyampaikan keluhan atas perlakuan petugas maupun sesama tahanan diberikan secara langsung kepada Kepala Lembaga Pemasyarakatan atau petugas yang bersifat urgent/fatal maka akan langsung kita proses, dan keluhan tersebut disampaikan secara lisan maupun tulisan sesuai dengan tata tertib Lembaga Pemasyarakatan. Dan jika perlakuan petugas ataupun tahanan lainnya tidak terlalu fatal maka petugas hanya akan menegur orang yang melakukan perbuatan tersebut. ${ }^{19}$

Berdasarkan hal tersebut, menurut penulis hal ini kurang efisien untuk dilakukan ditambah lagi tahanan merasa canggung dan takut untuk menyampaikan keluh kesahnya kepada petugas karena terkadang petugas menganggap perlakuan sesama tahanan ini tidak serius, sehingga beberapa tahanan merasa tidak puas dengan penyelesaian masalah yang ada setelah mereka menyampaikan keluhan.

f. Hak Mendapatkan Bahan Bacaan dan Siaran Media Massa

Di Lembaga Pemasyarakatan Klas IIA Jambi telah disediakan perpustakaan bagi tahanan dan narapidana. Perpustakaan tersebut berisikan buku-buku tentang buku agama, ilmu pengetahuan dan kejuruan. Jadwal peminjaman buku dapat dilakukan setiap hari. Selain itu, Lembaga Pemasyarakatan Klas IIA Jambi juga menyediakan siaran media massa berupa televisi di setiap blok hunian. Menurut penulis pelaksanaan hak mendapatkan bahan bacaan dan siaran media massa sudah dioptimalkan semaksimal mungkin. Dengan fasilitas yang sangat minim, pihak lapas masih mampu memberikan fasilitas perpustakaan dan siaran media massa.

g. Hak Mendapatkan Kunjungan

19 Hasil wawancara dengan Bapak Suprihadi, Kepala KPLP Lembaga Pemasyarakatan Klas IIA Jambi, pada tanggal 27 Mei 2019. 
Berkaitan dengan pelaksanaan hak mendapatkan kunjungan, keberadaan dan fungsi ruang kunjungan di Lapas sangat dibutuhkan. Lembaga Pemasyarakatan Klas IIA Jambi sebagai salah satu institusi yang menampung ratusan tahanan yang berasal dari kota jambi maupun dari luar kota jambi terus berupaya untuk meningkatkan pelayanan kunjungan, demi terciptanya kenyamanan kunjungan serta terpenuhinya hak tahanan. Kunjungan dilaksanakan sebanyak 6 (enam) hari, yaitu Senin sampai dengan Sabtu. Dilaksanakan mulai dari pukul 09.00 Wib s/d 11.30 Wib dan dilanjut pada pukul 13.00 Wib s/d 15.30 Wib. Tempatnya dipusatkan di ruangan kunjungan, gedung sisa kebakaran. Kunjungan dilakukan dengan beberapa Prosedur antara lain pemeriksaan kelengkapan dokumen, surat izin atau surat keterangan dan penggeledahan badan serta barang bawaan pengunjung. Serta dilakukan pembatasan waktu kunjungan sesuai dengan jadwal yang telah ditetapkan. Menurut penulis ruangan kunjungan masih dapat dikatakan kurang layak dikarenakan pengunjung disatukan dalam satu gedung tanpa adanya ruang privasi bagi tahanan. Ditambah ketika hari sabtu jumlah pengunjung akan lebih banyak dan kurangnya kipas angin yang mengakibatkan ruangan akan terasa sesak. Terkait dengan hal tersebut penulis melakukan wawancara dengan Bapak Dedi Antoni, dan mengatakan bahwa:

Pelaksanaan kunjungan telah diatur oleh petugas kunjungan yang telah ditugaskan secara bergiliran. Pihak Lapas sudah berusaha untuk memberikan ruang privasi bagi tahanan dengan cara membatasi jam kunjungan agar dapat bergantian, akan tetapi tetap dikoordinasi oleh petugas dan untuk fasilitas akan ditambahi lagi beberapa kipas angin di ruang kunjungan. Lembaga Pemasyarakatan Klas IIA Jambi semaksimal mungkin akan memenuhi hak tahanan. ${ }^{20}$

Berdasarkan hal tersebut menurut penulis bahwa Lapas Klas IIA Jambi sudah semaksimal mungkin melakukan kewajibannya untuk memenuhi hak kunjungan tahanan agar terpenuhi dengan baik.

h. Hak-hak Lainnya

Tahanan yang berada di Lapas Klas IIA Jambi diberikan kesempatan untuk menjadi anggota partai sesuai dengan aspirasinya. Selain itu tahanan juga diberikan kesempatan menggunakan hak pilihnya dalam pemilihan umum sesuai dengan peraturan perundang-undangan yang berlaku. Seperti pemilihan umum yang dilaksanakan pada tanggal 17 April 2019. Menurut hasil wawancara dengan bapak Suprihadi mengatakan bahwa:

20 Hasil wawancara dengan Bapak Dedi Antoni, Kasubsi Bimkemaswat Lembaga Pemasyarakatan Klas IIA Jambi, pada tanggal 27 Mei 2019. 
Pada pemilu kemaren kami juga mengadakan pemilu di lapas ini, ada 5 (lima) TPS disediakan bagi tahanan dan narapidana yang memiliki hak suara. Sebelum dilakukannya pemilihan, terlebih dahulu dilakukan sosialisasi dan simulasi pemilu yang bertujuan untuk memberikan pemahaman secara komprehensif kepada warga binaan di lapas tentang tata cara pemberian hak pilih yang benar sesuai dengan ketentuan yang berlaku serta pentingnya pelaksanaan pemungutan suara. Sebelumnya sudah dikonfirmasi jumlah pemilih yang memenuhi syarat dari pemilih. ${ }^{21}$

Penulis mendapati adanya tahanan yang tidak memberikan hak suaranya Menanggapi hal itu Bapak Dedi Antoni mengatakan: Banyak kendala yang dihadapi ketika pemilu, yaitu banjir dan kurangnya kertas suara. Kertas suara yang datang sebanyak 14 kertas suara kemudian disusul kembali sebanyak 354 kertas suara, jadi total kertas suara yang ada hanyalah 369 kertas suara. ${ }^{22}$ Bapak Suprihadi juga menambahkan bahwa:

Memang setelah pemilu yang diadakan pada tanggal 17 April 2019 pihak KPU mengirimkan surat kepada Kalapas untuk melakukan Pungutan Suara Ulang atau yang lebih sering disebut dengan istilah PSL. Dalam surat tersebut diberitahukan akan diadakan pada tanggal 26 April 2019 dan pemberitahuannya itu sangat mendadak. Berhubung dikarenakan pada tanggal 27 April 2019 merupakan Upacara Hari Bakti Pemasyarakatan ke 55 secara Nasional. Maka Kalapas mengirimkan surat balasan terkait dalam pelaksanaan PSL. Dalam surat tersebut dijelaskan, jika pada tanggal 26 April 2019 akan dilaksanakan gladi kotor pada jam 08.00 dan gladi bersih pada jam 16.00 dalam rangka memperingati Hari Bakti Pemasyarakatan ke 55 yang pelaksanaan dilaksanakan di Lapas Klas II A Jambi. Dan untuk diketahui, batas untuk melakukan PSL, PSU dan PSS harus dilakukan selama 10 hari setelah pemilu di laksanakan, yakni sejak 17 April 2019 dan paling lambat 27 April 2019. Jadi pelaksanaan Pungutan Suara Ulang tidak dilaksanakan kembali. ${ }^{23}$

Menurut penulis bahwa pelaksanaan hak politik dan keperdataan di Lembaga Pemasyarakatan Klas IIA Jambi masih perlu diperbaiki. Kurangnya komunikasi Lapas dengan Pihak Penyelengara Pemilu mengakibatkan banyaknya tahanan yang kehilangan hak suaranya pada pemilu 17 April 2019.

2. Kendala yang dihadapi dalam pemenuhan hak tahanan Di Lembaga Pemasyarakatan Klas IIA Jambi

Secara umum pelaksanaan hak tahanan menurut PP No. 58 Tahun 1999 dalam Lembaga Pemasyarakatan Klas IIA Jambi sudah dapat dikatakan baik. Namun demikian, dalam pelaksanaannya masih menemukan beberapa kendala terhadap

21 Hasil wawancara dengan Bapak Suprihadi, Kepala KPLP Lembaga Pemasyarakatan Klas IIA Jambi, pada tanggal 27 Mei 2019.

22 Hasil wawancara dengan Bapak Dedi Antoni, Kasubsi Bimkemaswat Lembaga Pemasyarakatan Klas IIA Jambi, pada tanggal 27 Mei 2019.

23 Hasil wawancara dengan Bapak Suprihadi, Kepala KPLP Lembaga Pemasyarakatan Klas IIA Jambi, pada tanggal 27 Mei 2019. 
pemenuhan hak tersebut. Adapun kendala-kendala yang dialami Lembaga Pemasyarakatan Klas IIA Jambi dalam memberikan hak tahanan adalah sebagai berikut:

1. Keadaan Lembaga Pemasyarakatan Klas IIA Jambi yang mengalami over kapasitas (daya tampung Lapas Klas IIA Jambi tidak sebanding dengan jumlah warga binaan pemasyarakatan). Lapas Klas IIA Jambi memiliki daya tampung sebanyak 218 orang, sedangkan lapas ini dihuni sebanyak 1381 orang warga binaan yang terdiri dari 405 orang tahanan dan 976 orang narapidana, sehingga over kapasitas yang dialami sebanyak 1163 orang. Hal ini diperkuat dengan wawancara dengan bapak Suprihadi yang mengatakan bahwa: "Jumlah warga binaan Lembaga Pemasyarakatan Klas IIA Jambi sudah sangat jauh melewati kapasitas daya tampungnya, keadaan yang over kapasitas ini menyebabkan petugas kewalahan dalam menempatkan para tahanan di blok hunian"24.

2. Keterbatasan sarana dan prasarana yang mendukung terlaksananya pemenuhan hak tahanan seperti kipas angin untuk ruang kunjungan, jenis-jenis buku perpustakaan, lapangan bulu tangkis dan blok hunian yang sangat sempit. Penulis melakukan wawancara dengan Aldi “Dalam kamar itu dihuni 13 orang tahanan, kalo malam kita kadang ganti-gantian, ada yang baring dan ada yang duduk, ruangannya sangat sempit". ${ }^{25}$ Bapak Dedi Antoni juga membenarkan bahwa sarana dan prasarana di Lembaga Pemasyarakatan Klas IIA Jambi memang sangat terbatas. Upaya menyampaikan keluhan ke pusat sudah dilaksanakan, namun belum ada perbaikan dan penambahan sarana dan prasarana. $^{26}$

3. Kurangnya tenaga pengajar pembinaan, tenaga kesehatan dan tenaga bantuan lainnya. Hal ini berkaitan dengan kurangnya Sumber Daya Manusia (SDM) yang ada di Lembaga Pemasyarakatan Klas IIA Jambi dan mengakibatkan adanya rangkap tugas dan jabatan. Menurut bapak Suprihadi

Lapas Klas IIA Jambi dalam menjalankan tugasnya tidak dapat terlaksana dengan baik tanpa adanya bantuan-bantuan yang diberikan oleh kementerian agama dan lembaga lembaga kemasyarakatan sosial lainnya. Hal ini dikarenakan jumlah petugas yang ada di Lapas Jambi masih kurang, yang mengakibatkan adanya rangkap tugas dan jabatan. Dan dalam hal kesehatan dokter tidak tersedia 24 jam di Lapas, jadi pihak Lapas juga

\footnotetext{
24 Hasil wawancara dengan Bapak Suprihadi, Kepala KPLP Lembaga Pemasyarakatan Klas IIA Jambi, pada tanggal 27 Mei 2019.

25 Hasil wawancara dengan Aldi, Tahanan Lembaga Pemasyarakatan Klas IIA Jambi, pada tanggal 27 Mei 2019.

26 Hasil wawancara dengan Bapak Dedi Antoni, Kasubsi Bimkemaswat Lembaga Pemasyarakatan Klas IIA Jambi, pada tanggal 27 Mei 2019
} 
bekerja sama dengan Puskesmas Rawa Sari untuk membantu petugas memberikan hak tahanan. ${ }^{27}$

4. Tidak semua tahanan bersedia mengikuti program-program yang dilaksanakan oleh Lembaga Pemasyarakatan. Program binaan merupakan wujud dari pemenuhan beberapa hak tahanan. Ketidakmauan tahanan untuk menikuti program yang ada mengakibatkan terhambatnya pemenuhan hak bagi tahanan. Menurut hasil wawancara penulis dengan responden, mereka mengatakan malas, bosan, dan jenuh terhadap kegiatan yang dilaksanakan oleh petugas Lapas. ${ }^{28}$ Kurangnya motivasi dalam diri tahanan untuk mengikuti program yang diberikan sangat disesalkan oleh petugas Lapas. Kesungguhan petugas untuk memenuhi hak tahanan tidak sejalan dengan minat para tahanan untuk mendapatkan apa yang menjadi hak mereka.

5. Terbatasnya anggaran Dana yang dimiliki oleh Lembaga Pemasyarakatan Klas IIA Jambi. Menurut penulis anggaran dana dalam upaya penyelenggaraan pemenuhan hak tahanan sangat menentukan, misalnya dalam pemenuhan fasilitas ruang kunjungan, kipas angin, buku, blok hunian, perawatan makanan serta perawatan kesehatan. Dalam melaksanakan semua itu lapas membutuhkan sangat banyak dana untuk dipergunakan, bapak Dedi juga menambahkan dana yang ada untuk melaksanakan kegiatan dalam pemenuhan hak tahanan sangat terbatas bahkan dapat dikatakan tidak sebanding dengan pengeluaran.

\section{Simpulan}

Pelaksanaan hak tahanan di wilayah hukum kota Jambi khususnya tahanan yang berada di Lembaga Pemasyarakatan Klas IIA Jambi masih belum efektif terkait beberapa hak, yaitu kurangnya tenaga medis bagi layanan kesehatan, hak menyampaikan keluhan dimana keluhan tahanan kurang mendapat tanggapan dari petugas lapas serta keluhan yang tidak tersampaikan dengan baik kepada Kalapas, hak mendapatkan kunjungan yang kurang nyaman serta tidak semua tahanan mempergunakan hak pilihnya dalam pemilu. Dalam hal pemenuhan hak tahanan, terdapat adanya hak tahanan yang terlaksana dengan baik dan kurang terlaksana dengan baik. Meskipun pihak Lapas telah berusaha untuk memaksimalkan pemenuhan hak tahanan sesuai dengan ketentuan yang berlaku, tetapi terdapat kendala yang dialami diantaranya: over kapasitas, keterbatasan sarana dan

\footnotetext{
${ }^{27}$ Hasil wawancara dengan Bapak Suprihadi, Kepala KPLP Lembaga Pemasyarakatan Klas IIA Jambi, pada tanggal 27 Mei 2019.

${ }^{28}$ Hasil wawancara dengan Subur, Tahanan Lembaga Pemasyarakatan Klas IIA Jambi, pada tanggal 27 Mei 2019.
} 
prasarana, kurangnya tenaga pengajar pembinaan, tenaga kesehatan, ketertiban dan tenaga bantuan lainnya, tidak semua tahanan bersedia mengikuti program yang diberikan terbatasnya anggaran dana yang dimiliki.

\section{DAFTAR PUSTAKA}

\section{Dokumen Hukum}

Undang-Undang Dasar 1945 Amandemen kelima

Republik Indonesia, Undang-Undang Tentang Hukum Acara Pidana. UU Nomor 8 Tahun 1981.

Republik Indonesia, Undang-Undang Tentang Kekuasaan Kehakiman. Nomor 48 Tahun 2009 Tentang Kekuasaan Kehakiman. LNRI Nomor 157.Peraturan Menteri Kehakiman RI. Nomor M.03UM.01.06 Tahun 1983 Tentang Penetapan Lembaga Pemasyarakatan Tertentu sebagai Rumah Negara

PerMenKeh RI No.M.04.UM.01.06 Tahun 1983 tentang Tata Cara Penempatan, Perawatan Tahanan dan Tata Tertib Rutan

PP No. 58 Tahun 1999 Tentang Syarat-syarat dan Tata Cara Pelaksanaan Wewenang, Tugas dan Tanggung Jawab Perawatan Tahanan.

Buku

Atmasasmita Romli, Sistem Peradilan Pidana Kontempores. Kencana, Jakarta, 2008.

M. Yahya Harahap. Pembahasan permasalahan Dan Penerapan KUHAP Penyidikan Dan Penuntutan. Edisi Kedua. Sinar Grafika, Jakarta, 2014.

Lopa Baharudin, Declaration Of Human Right Kejahatan Korpprasi dan Penagakan Hukum. Sinar Grafika. Jakarta. 2009.

Leden Marpaung. Proses Penanganan Perkara Pidana (Penyelidikan dan Penyidikan). Edisi Kedua. Sinar Grafika, Jakarta, 2014.

Bahder Johan Nasution. Negara Hukum dan Hak Asasi Manusia. Mandar Maju, Jambi, 2014.

Priyatno Dwija. Sistem Pelaksanaan Pidana Penjara di Indonesia. Refika Aditama, Bandung, 2006.

Samosir Djisman. Penologi dan Pemasyarakatan, Nuansa Aulia, Bandung. 2012

Sujatno Adi. Pencarahan di Penjara. Refika Aditama, Bandung, 2008.

H Soeharto. Perlindungan Hak Tersangka, Terdakwa dan Korban Tindak Pidana Terorisme dalam Sistem Peradilan Pidana Indonesian. PT Refika Aditama, Bandung, 2007.

Tolib Effendi. Dasar-Dasar Hukum Acara Pidana. Setara Press, Malang, 2014. 
Jurnal

Hafrida, Yulia Monita, Elizabeth Siregar. Publikasi Pendidikan Jurnal Pemikiran, Penelitian, dan Pengabdian Masyarakat Bidang Pendidikan, Volume V Nomor 3 , 2015, hal.201. https://ojs.unm.ac.id/index.php/pubpend/article/view/1613/0 